\title{
CHAPTER E: GEOCHEMICAL INTERPRETATION OF SAMPLES OF IGNEOUS ROCKS FROM NORTHEAST TANACROSS
}

Alicja Wypych ${ }^{1}$

\section{INTRODUCTION}

During a span of two summer field seasons in 2017 and 2018 geologists from the Alaska Division of Geological \& Geophysical Surveys (DGGS) carried out a geologic mapping and geochemical sampling project in the northeast Tanacross map area. Modern, high quality geochemical data were collected for 490 samples. This report focuses on the igneous subset of the samples collected, which are split into five major groups based on crystallization ages (Andronikov and Mukasa, 2010; Blondes and others, 2007; Todd and others, 2019; Wypych and others, 2020b), geochemical composition, and textural differences: 1) Triassic granites and granodioritic porphyries, 2) mid-Cretaceous granites and pegmatites, 3) Late Cretaceous dioritic to granitic porphyries, 4) Late Cretaceous andesite to rhyolite volcanic rocks, and 5) Quaternary basalts to basaltic trachyandesites (figs. 1, 2A and 2B). Petrological and geochemical investigations further distinguished igneous rock types associated with mineral occurrences as described in chapter F (Twelker and Newberry, 2021). Intrusive suites include the ca. $205 \mathrm{Ma}$ Witherspoon porphyry, ca. $110 \mathrm{Ma}$ granite and pegmatite, ca. 110 Timber pluton, suspected ca. 110 Fred granite, ca. $70 \mathrm{Ma}$ Taurus granodiorite, ca. $70 \mathrm{Ma}$ quartz-feldspar porphyry, and ca. $70 \mathrm{Ma}$ Pika diorite (Wypych and others, 2018) all of which are shown on the total alkali $\left(\mathrm{Na}_{2} \mathrm{O}+\mathrm{K}_{2} \mathrm{O}\right)$ versus silica $\left(\mathrm{SiO}_{2}\right)$ diagram (TAS) for intrusive rocks (fig. 2A; Cox and others, 1979; Wilson, 1989). The plutonic rocks exhibit a range of intermediate to felsic compositions. As with the intrusive suites, the volcanic rocks have a broad composition ranging from mafic to silicic $\left(\mathrm{SiO}_{2}\right.$ from 43 to $\left.76 \mathrm{wt} . \%\right)$ illustrated on the TAS diagram for volcanic rocks (fig. 2B; LeBas and others 1986), and are divided into two groups: ca. $70 \mathrm{Ma}$ volcanic flows and $176 \mathrm{ka}$ basanites.

All major and trace element compositions used in this report can be obtained as raw data files (Wypych and others, 2017; Wypych and others, 2018). A supplemental spreadsheet that relates map units to samples from the geochemical reports used for this interpretation can be download from doi.org/10.14509/30542. See Wypych and others (2017, doi.org/10.14509/29778; 2018, doi.org/10.14509/30113) for full documentation of the sample collection, preparation, and analytical methods.

\section{GEOLOGIC BACKGROUND}

Previous geologic investigations in the eastern Yukon Tanana Uplands region suggest periods of Triassic to Paleocene igneous activity (Foster, 1970, 1967; Gill, 1977; Harrington, 2010; Werdon and others, 2001; Szumigala and others, 2002). Foster (1970) describes the presence of felsic lavas, tuffs, tuff breccias, pumice-breccias, volcanic conglomerates and tuffaceous sediments as well as mafic lavas, breccias and tuffs in the region, and assigned them a Tertiary age based on pollen fossils found in the sedimentary units. Along with the Tertiary volcanic rocks, Foster (1970) describes equigranular to porphyritic diorite to granite intrusions of Mesozoic age. Gill (1977) conducted a detailed study of the area around the Pika and Fishhook prospects and described the presence of diorite, monzodiorite and monzonite, granodiorite, gabbro, multiple andesitic volcanic rocks, and basalt, all presumed to be Early Tertiary age. Harrington (2010) compiled previous industry reports focused on the Taurus prospect area and described Cretaceous granodiorite, along with

${ }^{1}$ Alaska Division of Geological \& Geophysical Surveys, 3354 College Rd., Fairbanks, Alaska 99709-3707. 


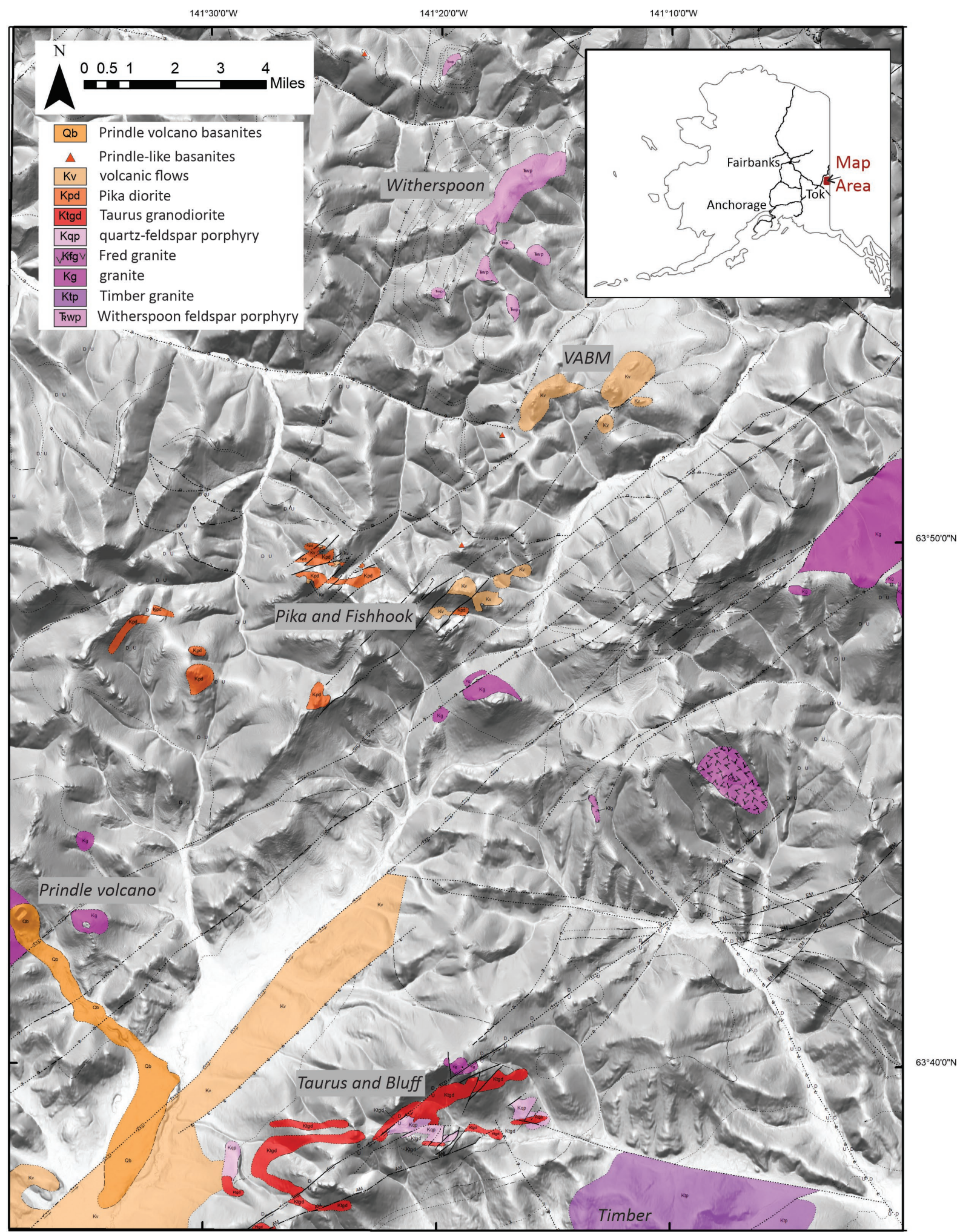

Figure 1. Geographic distribution of igneous units in the northeastern Tanacross map area (Wypych and others, 2021, sheet 1). — Kwp —Witherspoon feldspar porphyry; Ktp—Timber granite; Kg—granite; Kfg—Fred granite; Kqp— quartz-feldspar porphyry; Ktgd—Taurus granodiorite; Kpd—Pika diorite; Kv—volcanic flows; Qb—Prindle volcano and Prindle-like basanites. Thin dotted, dashed, and continuous fine lines signify unit contacts; thicker dotted, dashed, and continuous lines represent faults. 
Tertiary quartz monzonite porphyry, feldspar-quartz porphyry, quartz latite, quartz porphyry, intrusive breccia, and dacite. Here we compile, modify, and simplify these previous findings based on the research conducted by DGGS.

\section{TRIASSIC INTRUSIONS}

The oldest weakly metamorphosed to unmetamorphosed igneous rocks in the area are Triassic granites and granodioritic porphyries of the Witherspoon feldspar porphyry (kwp, fig. 1). This unit includes feldspar-rich dikes, plugs, and intrusions, with abundant chlorite and epidote alteration and slight foliation. They are granodioritic to granitic with $\mathrm{SiO}_{2}$ content between 65 and 74 wt.\%, some with elevated alkali contents (up to $8.5 \mathrm{wt} . \%$ total alkali) and one dioritic sample (fig. 2A). The samples are alkali-calcic to calc-alkalic, magnesian, and metaluminous to peraluminous (figs. 2C-E; Frost and others, 2001; Frost and Frost, 2008). The Witherspoon porphyry is characterized by relatively high strontium (Sr; up to 1300 parts per million [ppm]; fig. 3A) compared to other intrusions in the region, but lower concentrations of elements like lanthanum $(\mathrm{La})$, thorium $(\mathrm{Th})$, europium $(\mathrm{Eu})$ or ytterbium ( $\mathrm{Yb}$; figs. 3B-E). Relative to other intrusions in the region, this unit has lower rubidium $(\mathrm{Rb})$, yttrium $(\mathrm{Y})$, and niobium $(\mathrm{Nb})$ concentrations, which are typical of volcanic arc granitoids (fig. 3A; Pearce and others, 1984 ), and $\mathrm{Sr} / \mathrm{Y}$ ratios typical of adakitic melts (fig. 4E).

\section{MID-CRETACEOUS INTRUSIONS}

Mid-Cretaceous intrusions include the Timber granite pluton (Ktp), the Fred granite pluton $(\mathrm{Kfg})$ and other granite plutons and dikes (Kg; fig. 1). The units are generally coarse grained (up to pegmatitic), equigranular to porphyritic, and quartz rich, with biotite, minor hornblende, and accessory garnet. The granites all have greater than $70 \mathrm{wt} . \% \mathrm{SiO}_{2}$ and, in some cases, are enriched in alkalis (fig. 2A). Generally, the granites are calc-alkalic, ferroan (although the Timber granite does have a significant magnesian component), and peraluminous (figs. 2C-E). Trace element compositions of the granites are distinct from the Late Cretaceous and the Triassic intrusions, with lower $\mathrm{Sr}$ and zirconium $(\mathrm{Zr}$ ) concentrations (up to 473 and 477 ppm, respectively; figs. 3A and F). Fred granite has higher La concentration than the other mid-Cretaceous granites (fig. 3B); which are also characterized by low Eu concentrations (fig. 3D) typical of evolved rocks with plagioclase fractionation. On tectonic discrimination diagrams, the mid-Cretaceous samples are consistent with a volcanic arc origin, but some within-plate and syn-collisional affinity are also indicated (fig. 4B).

\section{LATE CRETACEOUS IGNEOUS ROCKS}

Late Cretaceous igneous rocks are divided into Taurus granodiorite (Ktgd) and quartz-feldspar porphyry (Kqp), Pika diorite (Kpd), and several occurrences of volcanic flows $(\mathrm{Kv})$ within the mapped area (fig. 1).

The Taurus granodiorite and Pika diorite have similar ages and are both porphyritic, medium-grained intrusive rocks characterized by the presence of hornblende. Tourmaline alteration is present in both, but more common in Taurus granodiorite. Taurus granodiorite has a tight range of $\mathrm{SiO}_{2}$ compositions between 64 and $70 \mathrm{wt} . \%$ (one outlier sample could be silicified, fig. 2A), whereas Pika diorite has a wide range of $\mathrm{SiO}_{2}$ compositions between 56 and 68 wt.\% (fig. 2A). Both the granodiorite and diorite are mostly calc-alkalic, magnesian, and metaluminous (with few exceptions, figs. 2C-E). The differences in silica concentration correlate with differences in trace element compositions, particularly the rare earth elements (figs. 3B-D). The Taurus granodiorite follows a separate fractionation trend than the Pika diorite, which is particularly well-highlighted by the $\mathrm{SiO}_{2}$ vs. Eu plot (fig. 3D) and has elevated $\mathrm{La}$, and $\mathrm{Rb}$ (figs. $3 \mathrm{~B}$ and F, fig. $4 \mathrm{C}$ and $\mathrm{D}$ ). Both the Taurus and Pika intrusions have volcanic arc granitoid signatures (figs. $4 \mathrm{C}$ and D).

A second distinctive intrusion in the Taurus area is the quartz porphyry (Kqp). This rock has a ca. 68 to 70 Ma crystallization age similar to the Taurus 

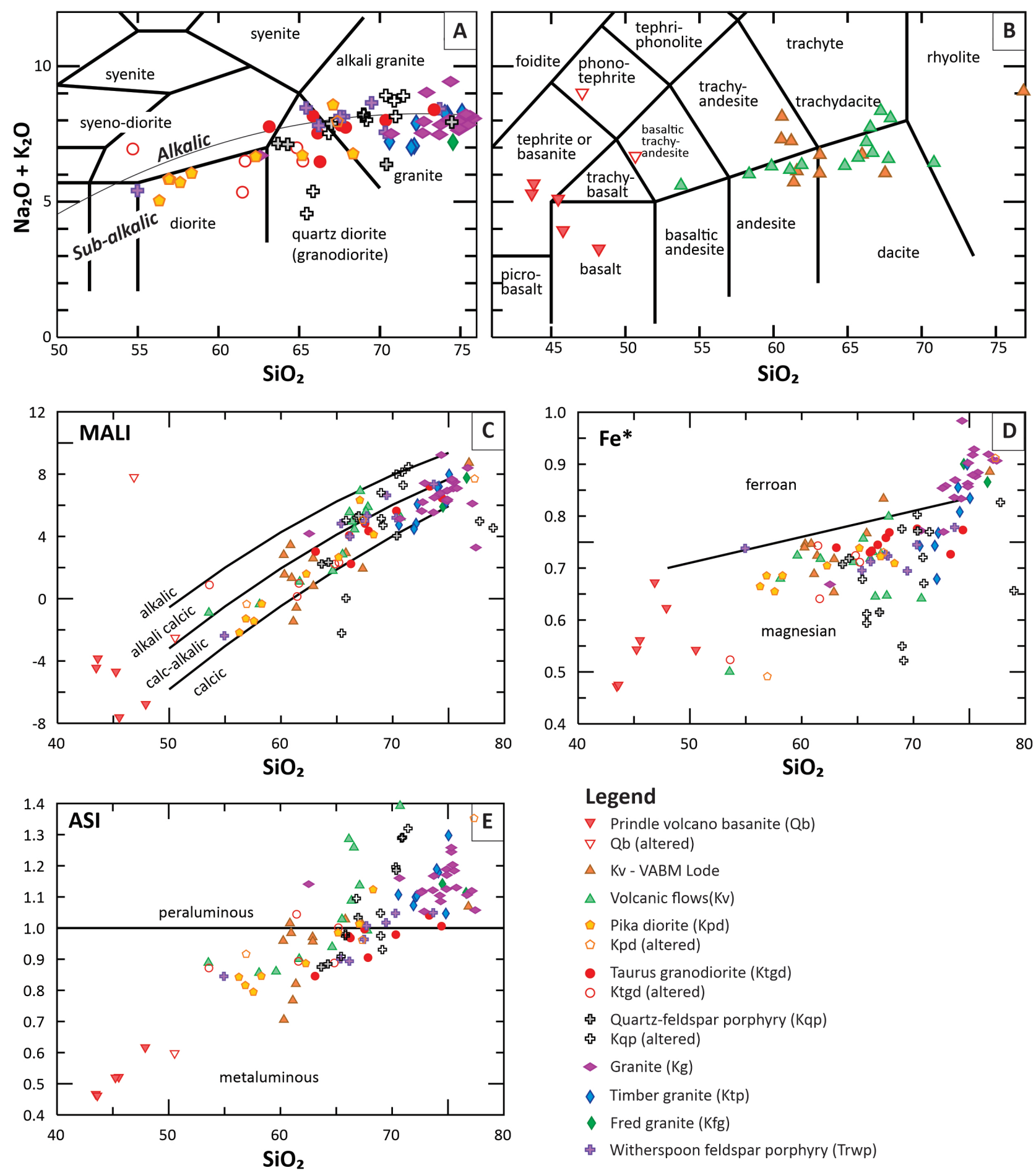

Legend

$\nabla$ Prindle volcano basanite (Qb)

$\nabla \mathrm{Qb}$ (altered)

$\triangle \mathrm{Kv}$ - VABM Lode

$\triangle$ Volcanic flows(Kv)

- Pika diorite (Kpd)

- Kpd (altered)

- Taurus granodiorite (Ktgd)

- Ktgd (altered)

\& Quartz-feldspar porphyry (Kqp)

↔ Kqp (altered)

- Granite (Kg)

$\checkmark$ Timber granite (Ktp)

$\checkmark$ Fred granite (Kfg)

* Witherspoon feldspar porphyry (Trwp)

Figure 2. Classification diagrams for igneous rocks from northeast Tanacross map area. A. Total alkali versus silica diagram with fields (labeled after Wilson, 1989) showing the compositional range of the plutonic rocks. B. Total alkali versus silica diagram with fields (after LeBas and others, 1986) showing the compositional range of the volcanic rocks. C. Modified alkalilime index (MALI $=\mathrm{Na}_{2} \mathrm{O}+\mathrm{K}_{2} \mathrm{O}-\mathrm{CaO}$; Frost and others, 2001). D. $\mathrm{Fe}^{*}=\left(\mathrm{FeO}_{\mathrm{tot}}\right) /\left(\mathrm{FeO}_{\mathrm{tot}}+\mathrm{MgO}\right)$; Frost and others, 2001). E. Aluminum saturation index diagram; $\mathrm{ASI}=\mathrm{Al} /(\mathrm{Ca}-1.67 \mathrm{P}+\mathrm{Na}+\mathrm{K})$; Frost and others, 2001). Oxide data have been normalized to 100 percent anhydrous. Open symbols signify samples described (in the field by the collector) as "altered;" Closed symbols represent samples described as "unaltered" or "fresh." 

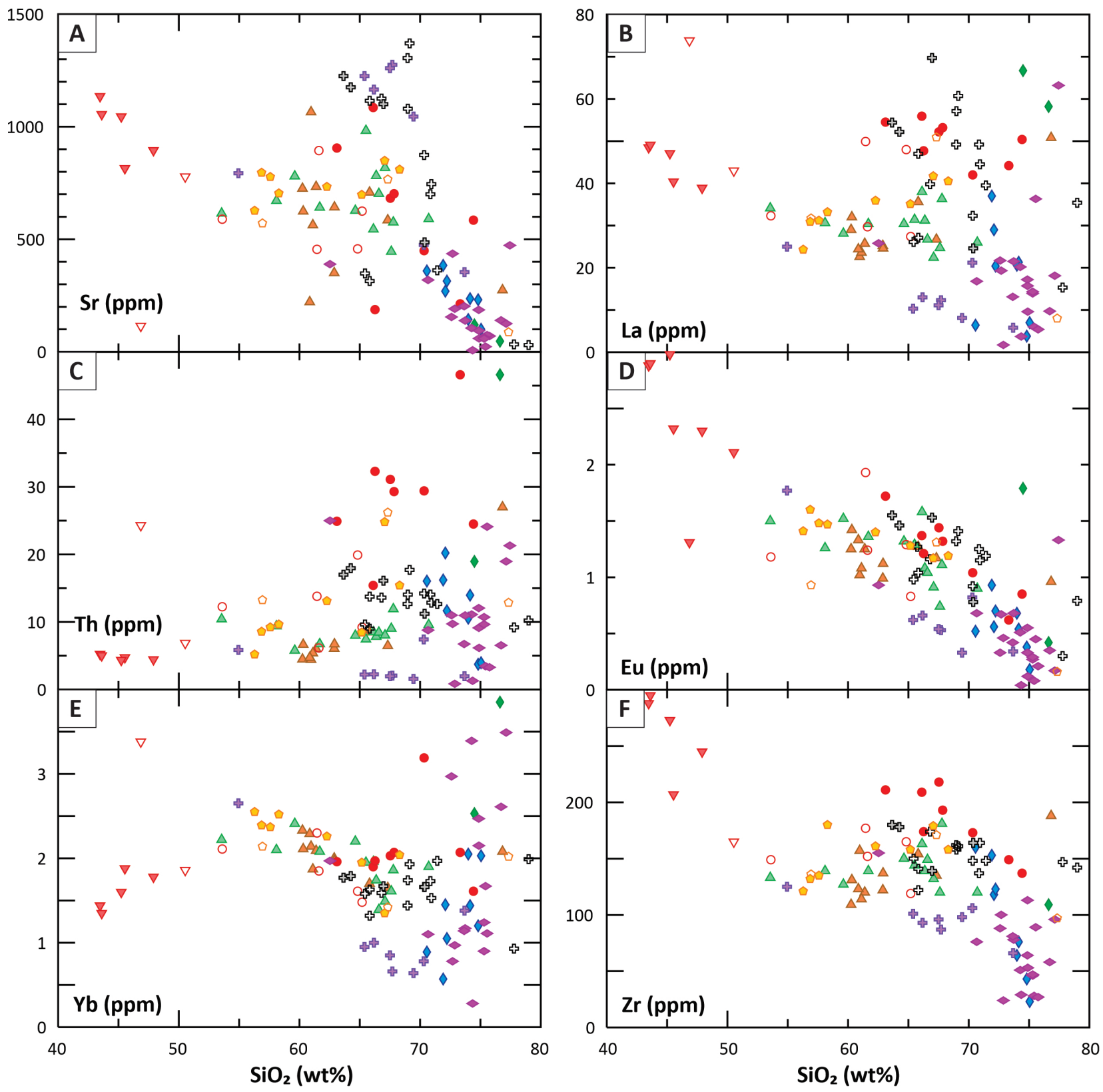

Figure 3. Bivariate plots of $\mathrm{SiO}_{2}$ (wt.\%) vs selected trace element abundances (ppm). Symbols and colors as in figure 2.

granodiorite (Todd and others, 2019). Based on relationships observed in hand samples we interpret this intrusion to be older than the granodiorite. This porphyry is fine grained, has phenocrysts of quartz, and is often highly altered to sericite. The samples with the least amount of alteration are of granodioritic to granitic composition (with 64 to $75 \mathrm{wt} . \%$ $\mathrm{SiO}_{2}$, fig. 2A), but the altered samples have elevated $\mathrm{K}_{2} \mathrm{O}$ and $\mathrm{Na}_{2} \mathrm{O}$ suggesting potassic and sodic alteration. The quartz porphyry is calc-alkalic, ferroan, and metaluminous to peraluminous (figs. 2C-E). Rare earth elements in the quartz porphyry are indistinguishable from the Taurus granodiorite (figs. 3B-E), but both $\mathrm{Th}$ and $\mathrm{Zr}$ concentrations are lower in the porphyry than in the granodiorite (figs. 3C and F) whereas Sr is generally higher (fig. 3A). The porphyry is of volcanic arc provenance and is similar to the Taurus granodiorite in the $\mathrm{Rb}$ vs $\mathrm{Y}+\mathrm{Nb}$ plot (fig. 4C). Some Taurus granodiorite samples have higher $\mathrm{Nb}$ and $\mathrm{Y}$ concentration (fig. 4C). 

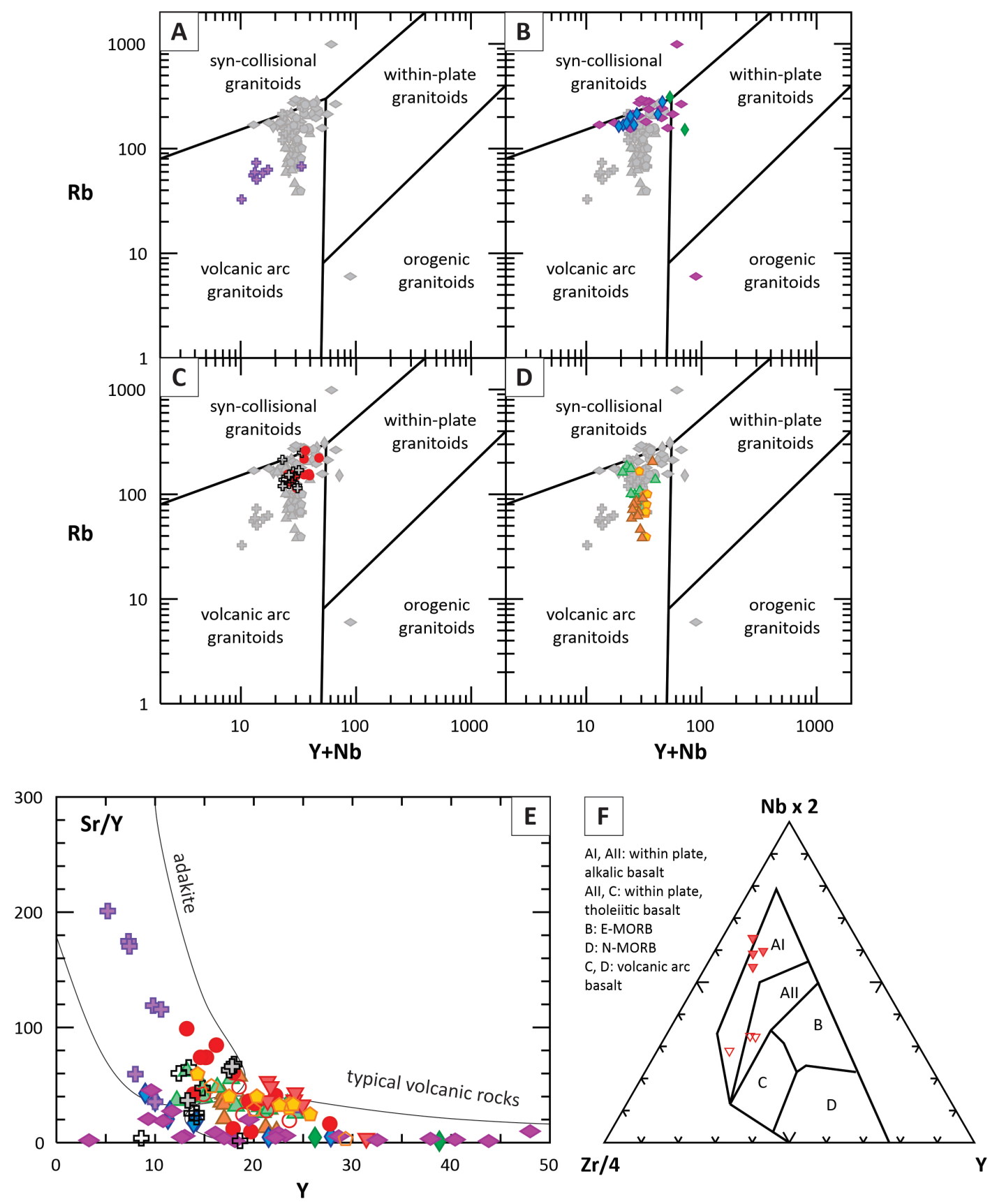

Figure 4. Tectonic classification diagrams for igneous rocks from the northeastern Tanacross area after Pearce and others (1984) for A. Witherspoon porphyry rocks; B. mid-Cretaceous granites; C. Taurus area intrusive rocks; and D. Pika-Fishhook area and VABM Lode volcanic rocks and the Pika diorite; E. Y versus Sr/Y bivariate diagram after Defant and others (1991); F. High field-strength element, tectonic discrimination ternary diagram for basalts (after Meschede,1986). Symbols and colors as in figure 2.

The volcanic flows observed in the Pika-Fishhook area and at VABM Lode are porphyritic with aphanitic matrix and feldspar phenocrysts, and are generally more siliceous than the Pika dioritespanning from andesite to dacite, with one basaltic sample and a couple of rhyolitic samples (fig. 2B).
Some samples have elevated alkali concentration, plotting them in trachyandesitic to trachydacitic fields on the TAS diagram (fig. 2B). The samples are calc-alkalic to alkali-calcic, mostly ferroan, and span between metaluminous and peraluminous (figs. 3C-E). In terms of trace element composi- 
tion, the volcanic rocks are indistinguishable from the Pika diorite (figs. 3A-F). On the Pearce (1984) diagram they lie along the same trend. One difference between them is that the volcanic rocks have slightly lower $\mathrm{Y}$ and $\mathrm{Nb}$ concentrations compared to the Pika diorite (fig. 4D). The similar trace element compositions of igneous rocks in the Pika-Fishhook area, the general major-element trend, and the proximity to the diorite lead us to believe that the volcanic rocks are an extrusive equivalent of the intrusive Pika diorite.

\section{QUATERNARY BASANITES OF PRINDLE VOLCANO}

The basanite of Prindle volcano (fig. 1) is a porphyritic black rock with aphanitic matrix and olivine phenocrysts. Samples are often vesicular and are characterized by the presence of numerous peridotitic and granulite xenoliths (Foster and others, 1966). Rocks with similar chemical composition and textural characteristics to the Prindle basanite have been observed further north in the map area and are included in the Prindle Volcano basanite unit for simplicity (fig. 1). Most of the samples analyzed are trachybasaltic to basanitic on the TAS diagram (fig. 2B), with few basaltic samples present. The basanites have a distinctive trace element composition, with very low $\mathrm{Th}$ and $\mathrm{Yb}$ concentration (figs. $3 \mathrm{C}$ and $\mathrm{E}$ ) and high Sr, La, Eu, and Zr (figs. 3A, B, D, and F). The majority of samples are of within-plate alkalic basalt affinity, with a couple tholeiitic within-plate basalts (Meschede, 1986; fig. 4F).

\section{CONCLUSIONS}

The magmatic activity in the Northeast Tanacross map area spans from Triassic to Quaternary and, apart from Prindle basanites, seems to be derived from volcanic arc activity (figs. $4 \mathrm{~A}-\mathrm{D}$ ). The magne- sian signature of mafic to intermediate Triassic and Late Cretaceous samples supports magma genesis under oxidized conditions (Frost and Frost, 2008), and elevated $\mathrm{Sr} / \mathrm{Y}$ ratios with relatively low La/ $\mathrm{Yb}$ suggest partial melting of lower crust (Moyen, 2009) or contamination with upper crust material. The mid-Cretaceous granites, similar to the other magmatic rocks in the region, have a volcanic arc affinity (fig. 4B), however, the elevated $\mathrm{Rb}$ and $\mathrm{Al}_{2} \mathrm{O}_{3}$, (figs. $4 \mathrm{~B}$ and $2 \mathrm{E}$ ) suggest crustal melt input. Longer residency in the crust suggested by presence of an Eu anomaly (Wypych and others, 2017, 2018) could facilitate significant crustal melt input in the magma chamber. Finally, the volcanic rocks of Prindle volcano have a separate melt origin that indicates a deep, more-fertile magma source and is consistent with the presence of fertile mantle xenoliths (Todd, 2019, personal commun.) and within-plate tectonic affinity (fig. 4F).

\section{ACKNOWLEDGMENTS}

The author would like to thank the DGGS Mineral Resources section and DGGS staff who contributed to the data collection, scientific discussions and other necessary support. The DGGS Northeast Tanacross project was primarily funded by State of Alaska general funds, with supplementary funding from the USGS National Cooperative Geologic Mapping Program under STATEMAP award number G18AC00137 for 2018. The views and conclusions contained in this document are those of the authors and should not be interpreted as necessarily representing the official policies, either expressed or implied, of the U.S. Government.

The author would like to thank Dr. Erin Todd and Robert Gillis for providing insightful discussion and contributing to the accuracy of this report. 


\section{REFERENCES}

Andronikov, A.V., and Mukasa, S.B., 2010, ${ }^{40} \mathrm{Ar} /{ }^{39} \mathrm{Ar}$ eruption ages and geochemical characteristics of Late Tertiary to Quaternary intraplate and arcrelated lavas in interior Alaska: Lithos, v. 115, no. $1-4$, p. $1-14$.

Blondes, M.S., Reiners, P.W., Edwards, B.R., and Biscontini, Adrian, 2007, Dating young basalt eruptions by $(\mathrm{U}-\mathrm{Th}) / \mathrm{He}$ on xenolithic zircons: Geology, v. 35, no. 1, p. 17-20.

Cox, K.G., Bell, J.D., and Pankhurst, R.J., 1979, The Interpretation of Igneous Rocks: Allen and Unwin, London.

Defant, M.J., Richerson, P.M., DeBoer, J.Z., Stewart, R.H., Maury, R.C., Bellon, H., Drummond, M.S., Feigenson, M.D., Jackson, T.E., 1991, Dacite genesis via slab meltingand differentiation: petrogenesis of La Yeguada volcanic complex, Panama: Journal of petrology v. 42, p. 1,101-1,142.

Foster, H.L., 1967, Geology of the Mount Fairplay area, Alaska: U.S. Geological Survey Bulletin 1241-B, p. B1-B18.

1970, Reconnaissance Geologic Map of the Tanacross Quadrangle, Alaska: U.S. Geological Survey Miscellaneous Geologic Investigations Map 593, 1 sheet, scale 1:250,000.

Foster, H.L., Forbes, R.B., and Ragan, D.M., 1966, Granulite and peridotite inclusions from Prindle Volcano, Yukon-Tanana Upland, Alaska, U.S. Geological Survey Professional Paper 550-B, p. B115-B119.

Frost, B.R., Barnes, C.G., Collins, W.J., Arculus, R.J., Ellis, D.J., and Frost, C.D., 2001, A geochemical classification for granitic rocks: Journal Of Petrology, v. 42, no. 11, p. 2033-2048.

Frost, B.R., and Frost, C.D., 2008, A Geochemical Classification for Feldspathic Igneous Rocks: Journal of Petrology, v. 49, no. 11, p. 1955-1969.

Gill, R.D., 1977, Geology and mineral deposits of the southwest quarter of the Tanacross D-1 quadrangle, Alaska: Golden, Colorado School of Mines, M.Sc. thesis, 129 p.

Harrington, Edward, 2010, Taurus Property: Technical Report for Senator Minerals Inc., 133 p. (posted on www.sedar.com)
LeBas, M.J., LeMaitre, R.W., Streckeisen, A., and Zanettin, B., 1986, A Chemical Classification of Volcanic Rocks Based on the Total AlkaliSilica Diagram: Journal of Petrology, v. 23, no. 3, p. $745-750$.

Meschede, Martin, 1986, A method of discrimination between different types of mid-ocean ridge basalts and continental tholeiites with the $\mathrm{Nb}-\mathrm{Zr}-\mathrm{Y}$ diagram: Chemical Geology, v. 56, p. 207-218.

Moyen, J.-F., 2009, High Sr/Y and La/Yb ratios: The meaning of the "adakitic signature": Lithos, v. 112 , no. 3-4, p. 556-574.

Pearce, J.A., Harris, N.B., and Tindle, A.G., 1984, Trace element discrimination diagrams for the tectonic interpretation of granitic rocks: Journal of Geophysical Research, v. 103, p. 7,171-7,186.

Szumigala, D.J., Newberry, R.J., Werdon, M.B., Athey, J.E., Stevens, D.S.P., Flynn, R.L., Clautice, K.H., and Craw, P.A., 2002, Geologic map of the Eagle A-1 Quadrangle, Fortymile mining district: Alaska Division of Geological \& Geophysical Surveys Preliminary Interpretive Report 2002-1A, 1 sheet, scale 1:63,360. doi. org/10.14509/2863

Todd, Erin, Wypych, Alicja, and Kylander-Clark, Andrew, 2019, U-Pb and Lu-Hf isotope, age, and trace element data from zircon separates from the Tanacross D-1, and parts of D-2, C-1 , and C-2 quadrangles: Alaska Division of Geological \& Geophysical Surveys Raw Data File 2019-5, 10 p. Twelker, Evan, and Newberry, R.J., 2021, Chapter F: Observations on the economic geology of the northeast Tanacross map area, in Wypych, Alicja, Northeast Tanacross geologic mapping project, Alaska: Alaska Division of Geological \& Geophysical Surveys Report of Investigation 20209F. doi.org/10.14509/30557

Werdon, M.B., Newberry, R.J., Szumigala, D.J., and Pinney, D.S., 2001, Geologic map of the Eagle A-2 Quadrangle, Fortymile mining district, Alaska: Alaska Division of Geological \& Geophysical Surveys Preliminary Interpretive Report 2001-3A, 1 sheet, scale 1:63,360, v. 1.0.1. doi.org/10.14509/2669 
Wilson, Marjorie, 1989, Igneous petrogenesis: Unwin Hyman, London, 466 p.

Wypych, Alicja, Hubbard, T.D., Naibert, T.J., Athey, J.E., Newberry, R.J., Sicard, K.R., Twelker, Evan, Werdon, M.B., Willingham, A.L., Wyatt, W.C., and Lockett, A.C., 2021, Chapter B: Northeast Tanacross geologic map and map units and descriptions, in Wypych, Alicja, Northeast Tanacross geologic mapping project, Alaska: Alaska Division of Geological \& Geophysical Surveys Report of Investigation 2020-9B. doi.org/10.14509/30539

Wypych, Alicja, Jones, J.V., III, and O'Sullivan, P., 2020b, U-Pb zircon ages from bedrock samples collected in the Tanacross D-1, and parts of D-2, C-1 and C-2 quadrangles, Alaska : Alaska Division of Geological \& Geophysical Surveys Preliminary Interpretive Report 2020-2, 19 p. doi.org/10.14509/30465
Wypych, Alicja, Naibert, T.J., Athey, J.E., Newberry, R.J., Sicard, K.R., Twelker, E., Werdon, M.B., Willingham, A.L., and Wyatt, W.C., 2018, Major-oxide and trace-element geochemical data from rocks collected in 2018 for the Northeast Tanacross project, Tanacross C-1, C-2, D-1, and D-2 quadrangles, Alaska: Alaska Division of Geological \& Geophysical Surveys Raw Data File 2018-4, 4 p. doi.org/10.14509/30113

Wypych, Alicja, Twelker, E., Athey, J.E., Lockett, A.C., Naibert, T.J., Sicard, K.R., Werdon, M.B., and Willingham, A.L., 2017, Major-oxide and trace-element geochemical data from rocks collected in the Tanacross C-1, D-1, and D-2 quadrangles, Alaska in 2017: Alaska Division of Geological \& Geophysical Surveys Raw Data File 2017-10, 4 p. doi.org/10.14509/29778 